\title{
Hematological and hemostaseological alterations after warm and cold limb ischemia-reperfusion in a canine model ${ }^{1}$
}

\author{
Alterações hematológicas e hemostaseológicas após isquemia-reperfusão morna e fria \\ de membro inferior em modelo canino
}

\author{
Miklos Szokoly', Norbert Nemeth", Istvan Furka ${ }^{\text {III }}$, Iren Miko ${ }^{\text {IV }}$ \\ ${ }^{\text {I }} \mathrm{PhD}$, Chief-Doctor, National Institute of Traumatology, Budapest. \\ II PhD, Assistant Professor, Head of Research Laboratory, Department of Operative Techniques and Surgical Research, Institute of Surgery, Medical and \\ Health Science Center, Faculty of Medicine, University of Debrecen, Hungary. \\ III PhD, D.Sc., Full Professor, Head of Microsurgical Education and Training Center, Department of Operative Techniques and Surgical Research, \\ Institute of Surgery, Medical and Health Science Center, Faculty of Medicine, University of Debrecen, Hungary. \\ Iv PhD, Full Professor, Head of Department, Department of Operative Techniques and Surgical Research, Institute of Surgery, Medical and Health \\ Science Center, Faculty of Medicine, University of Debrecen, Hungary.
}

\begin{abstract}
Purpose: Acute ischemia-reperfusion (I/R) of extremities means serious challenge in the clinical practice. Furthermore, the issue of preventive cooling is still controversial. In this canine model we investigated whether limb I/R -with or without cooling- has an influence on hematological and hemostaseological factors. Methods: Femoral vessels were exposed and clamped for 3 hours. After release the clamps, 4-hour reperfusion was secured. The same procedures with cooling using ice bags, as well as warm and cold sham-operations were performed. Before operations, from the excluded limb by the end of ischemia, during the reperfusion, and for 5 postoperative days afterwards blood samples were collected for testing hematological and blood coagulation parameters. Results: After I/R activated partial thromboplastin time was elongated on 2 nd-4th postoperative days. The highest values were on the 2 nd day in cold I/R group, accompanied by increased prothrombin time values. The hematological parameters and fibrinogen level showed non-specific changes. In excluded ischemic limb the blood composition showed controversial data. Cold ischemia induced larger alterations, however platelet count, hematocrit changed more expressly in warm ischemia.Conclusion: These results indicate the risk of coagulopathy following limb $\mathrm{I} / \mathrm{R}$ on early post-eventually days, which risk is higher in the case of cold I/R.
\end{abstract}

Key words: Ischemia. Reperfusion. Lower Extremity. Cooling. Blood Coagulation. Hematology. Dogs.

\section{RESUMO}

Objetivo: Isquemia-Reperfusão aguda (I/R) de extremidades representa um desafio sério na prática clínica. Além disso, o tema de prevenção pelo resfriamento é ainda controverso. Nesse modelo canino, investigou-se se $\mathrm{I} / \mathrm{R}$ de membros -com ou sem resfriamentotem influência nos fatores hematológicos e hemostaseológicos. Métodos: Os vasos femorais foram expostos e clampeados por 3 horas. Após liberação dos clampes, foi realizada a reperfusão por 4-horas. Os mesmos procedimentos com e sem resfriamento usando bolsas de gelo, assim como operações simuladas com e sem resfriamento foram realizados. Antes das operações, do membro excluído ao final da isquemia, durante a reperfusão e por 5 dias de pós-operatório, amostras sanguíneas foram colhidas para exames hematológicos e parâmetros de coagulação. Resultados: Após I/R, o tempo de tromboplastina parcial ativada foi alargado no $2^{\circ} .4^{\circ}$. dias de pós-operatório. Os valores mais altos foram no $2^{\circ}$. dia no grupo deI/R fria, acompanhada pelo aumento dos valores do tempo de protrombina. Os parâmetros hematológicos e o nível de fibrinogênio mostraram mudanças não específicas. No membro isquêmico excluído a composição sanguínea mostrou dados controversos. A isquemia fria induziu maiores alterações, entretanto, a contagem de plaquetas e o hematócrito mudaram mais expressivamente na isquemia morna. Conclusão: Estes resultados indicam risco de coagulopatia após I/R de membros nos dias mais precoces após o evento, sendo mais elevado no caso da I/R fria.

Descritores: Isquemia. Reperfusão. Extremidade Inferior. Esfriamento. Coagulação Sanguínea. Hematologia. Cães.

${ }^{1}$ Research performed at Laboratory, Department of Operative Techniques and Surgical Research, Institute of Surgery, Medical and Health Science Center, Faculty of Medicine, University of Debrecen, Hungary. 


\section{Introduction}

Acute limb ischemia and reperfusion means serious challenge in the clinical practice of trauma cases, when the duration and degree of ischemia and the temperature are variable factors. The connection between ischemia-reperfusion of extremities and multiple organ failure is well known evidence being a feared situation ${ }^{1}$. Special vigilance is needed during the replantation of traumatic amputated extremities as well. Several case reports and experiences are about the attempted replantation of arms or lower extremities following their traumatic amputation, furthermore, the occurred hyperkalemia, acidemia and severe hypotension, and sometimes ultimately the re-amputation was necessary to treat the complex systemic effects of the reperfusion or revascularisation syndrome ${ }^{2}$.

Ischemia-reperfusion results in complex alterations in hemodynamics as well as in endothelial function and microcirculation, causing local and systemic metabolic changes, and alters fluid equilibrium and induces complement and inflammatory pathways ${ }^{3-9}$. It is also known that disorders of the blood coagulation system may cause ischemic, ischemia-reperfusion processes, but simultaneously ischemia and reperfusion originated not from coagulation problem may alter the hemostasis too, like a circulus vitiosus.

Coagulopathy in patients with severe trauma shows a complex picture. It is mainly related to consumption and dysfunction of platelets and coagulation factors, resulting in either hypo- or hypercoagulable states ${ }^{10-11}$. Further questions rise in respect of cooling in traffic or crush accidents, or following traumatic limb amputation. Despite of the beneficial effect of preventive cooling, its optimum has not been clarified yet, furthermore, controversial data suggests that cooling does not mean always an advantage ${ }^{12-16}$.

We hypothesized that limb ischemia-reperfusion at normo- or hypothermia variously alters blood coagulation parameters. Earlier our team has developed a hind limb ischemiareperfusion experimental canine model in order to investigate local and systemic alterations in complex blood parameters ${ }^{17-18}$. In a previous paper the hemorheological alterations were reported ${ }^{19}$, in recent study we summarize the local and systemic hematological and hemostaseological changes.

\section{Methods}

\section{Animal care and preparation}

The experiments were approved by the Committee of Animals Research at University of Debrecen (UDCAR) (Permission Nr.: 50/2001. UDCAR). Twenty-four mongrel dogs (age: $3-4$ years, bodyweight: $23.79 \pm 4.05 \mathrm{~kg}$ ) were subjected to the study. The anesthesia was induced with ketamin $(10 \mathrm{mg} / \mathrm{kg})$ and xylazin-hydrochloride $(1 \mathrm{mg} / \mathrm{kg})$ intramuscularly, and was maintained using a half-dose per hour under control of electrocardiograph. Skin temperature on the thigh was regularly measured by a heat probe unit. On postoperative days animals received antibiotic and analgesic drugs given by a veterinary doctor.

\section{Operative technique}

The right external jugular vein was cannulated. The left femoral artery and vein were exposed, and then the animals were randomized into four groups ${ }^{17-19}$ :

Group I. warm sham-operation (warm Sh, n=6): the wound was left open for 7 hours and covered with sterile wet gauze, then the fascia lata and the skin was sutured. Skin average temperature on the thigh was $28.17^{\circ} \mathrm{C}$ during the operative period.

Group II. cold sham-operation (cold Sh, $\mathrm{n}=5$ ): ice bags were placed around the limb for 3 hours. Skin surface temperature was $5.1{ }^{\circ} \mathrm{C}$ in average. Then the ice bags were removed and the animals were left on the operating table for further 4 hours, so altogether for 7 hours.

Group III. warm ischemia-reperfusion (warm I/R, n=5): the femoral vessels were clamped for 3 hours using vascular clamps, while a sterile metal steel tourniquet was stretched around the thigh under the prepared vessels to close out the soft tissues. Skin temperature on the thigh was $28.02^{\circ} \mathrm{C}$ (mean). Four hours after releasing the vessels, the steel tourniquet was removed.

Group IV. cold ischemia-reperfusion (cold I/R, $n=8$ ): similarly to the Group II with cooling. Skin surface temperature was $4.9^{\circ} \mathrm{C}$ (mean).

\section{Sampling protocol}

Blood samples were collected from the cannulated external jugular vein before the femoral vessel preparation. In ischemia-reperfusion groups local blood samples were taken from the femoral vein of the excluded region just before releasing the clamp. From the external jugular vein further blood samples were collected after the 3-hour-ischemia at the beginning of the reperfusion ( $3 \mathrm{~h})$, at the $30 \mathrm{th}\left(3 \mathrm{~h}+30^{\prime}\right)$ and the $60 \mathrm{th}(3 \mathrm{~h}+60$ ') minute of reperfusion. In sham-operated animals the blood samples were taken in parallel. On the $1 \mathrm{st}-5$ th postoperative days the cephalic veins were used for daily blood sampling in each group.

\section{Laboratory tests}

\section{Determination hematological parameters}

A Sysmex F-800 microcell counter was used to determine the hematological parameters in blood samples anticoagulated with $\mathrm{K}_{3}$-EDTA $(7.5 \%, 0.04 \mathrm{ml})$. The determined main parameters were: white blood cell count (WBC, [G/l], with lymphocyte and granulocyte+monocyte ratios and counts), red blood cell count (RBC, [T/l]), hemoglobin level (Hgb, [g/dl]), hematocrit (Hct, [\%]), mean cell volume (MCV, [fl]), mean cell hemoglobin ( $\mathrm{MCH},[\mathrm{pg}])$, mean cell hemoglobin concentration $(\mathrm{MCHC},[\mathrm{g} / \mathrm{dl}])$, platelet count (Plt, [G/l]), mean platelet volume (MPV, [fl]).

\section{Measurement of coagulation factors}

For the measurements blood samples anticoagulated with sodium-citrate were used. Prothrombin time (PT, [sec]), activated partial thromboplastin time (APTT, [sec]), thrombin time (TT, [sec]) and fibrinogen concentration $(\mathrm{Fbg},[\mathrm{g} / \mathrm{l}])$ in plasma were determined by a Sysmex CA-500 automated coagulometer using standard reagents. 


\section{Determination of total protein and albumin levels}

Serum levels of total protein $[\mathrm{g} / \mathrm{l}]$, and albumin $[\mathrm{g} / \mathrm{l}]$ were determined by photometry.

\section{Statistical analysis}

Results are expressed as means and standard error (means \pm S.E.). The statistical analyses were carried out with nonparametric tests: For intra-group analysis ANOVA and Dunnett's tests, for inter-group comparisons Mann-Whitney rank sum and Kruskal-Wallis tests were used at $p$ value of $<0.05$ significance level.

\section{Results}

\section{Hematological parameters}

Red blood cell count (RBC) did not change significantly and were similar in each group. During the operative period there was a slight elevation in RBC that reached a maximum by the 1 st postoperative day and then decreased. The hematocrit showed similar alteration, however the decrease was significant by the 5 th day in the cold I/R group (Table 1). Mean cell volume (MCV), mean cell hemoglobin (MCH), and mean cell hemoglobin concentration (MCHC) did not show important changes.

TABLE 1 - Changes of red blood cell related hematological parameters

\section{Intraoperative samples}

\section{Ischemia}

Parameter Group Base 3

\begin{tabular}{|c|c|c|c|c|c|c|c|c|c|c|}
\hline RBC & w- Sh & $7.4 \pm 0.4$ & $7.6 \pm 0.3$ & $8.5 \pm 0.5$ & $7.6 \pm 0.2$ & $8.5 \pm 0.5$ & $6.5 \pm 0.2$ & $6.7 \pm 0.7$ & $6.6 \pm 0.3$ & $6.7 \pm 0.1$ \\
\hline \multirow[t]{3}{*}[\mathrm{T}/1]{} & c- Sh & $6.1 \pm 0.3$ & $6.5 \pm 0.4$ & $6.6 \pm 0.5$ & $6.5 \pm 0.4$ & $6.9 \pm 0.4$ & $5.8 \pm 0.3$ & $5.5 \pm 0.3$ & $5.5 \pm 0.2$ & $5.5 \pm 0.2$ \\
\hline & W- I/R & $7.2 \pm 0.4$ & $7.3 \pm 0.4$ & $7.4 \pm 0.4$ & $6.9 \pm 0.5$ & $7.6 \pm 0.5$ & $7.5 \pm 0.6$ & $6.9 \pm 0.7$ & $6.0 \pm 0.5$ & $6.2 \pm 0.6$ \\
\hline & $c-I / R$ & $7.0 \pm 0.4$ & $7.5 \pm 0.3$ & $7.5 \pm 0.4$ & $7.6 \pm 0.3$ & $7.8 \pm 0.6$ & $6.5 \pm 0.4$ & $6.6 \pm 0.3$ & $6.3 \pm 0.5$ & $5.7 \pm 0.4$ \\
\hline \multirow{4}{*}{$\begin{array}{c}\mathrm{Hgb} \\
{[\mathrm{g} / \mathrm{dl}]}\end{array}$} & w- Sh & $15 \pm 1.0$ & $16 \pm 0.8$ & $18 \pm 1.1$ & $16 \pm 0.9$ & $17 \pm 1.7 *$ & $13 \pm 0.6$ & $13 \pm 1.1$ & $12 \pm 0.9$ & $13 \pm 0.6$ \\
\hline & c- Sh & $14 \pm 0.7$ & $15 \pm 0.9$ & $16 \pm 1.2$ & $15 \pm 0.9$ & $16 \pm 0.7$ & $14 \pm 0.7$ & $13 \pm 0.6$ & $12 \pm 0.6$ & $12 \pm 0.6$ \\
\hline & W- I/R & $15 \pm 0.9$ & $15 \pm 1.1$ & $15 \pm 0.9$ & $15 \pm 1.0$ & $16 \pm 0.8$ & $16 \pm 1.1$ & $14 \pm 1.4$ & $13 \pm 1.1$ & $13 \pm 1.2$ \\
\hline & $c-I / R$ & $15 \pm 0.7$ & $16 \pm 0.5$ & $16 \pm 0.7$ & $16 \pm 0.6$ & $17 \pm 1.6$ & $14 \pm 1.1$ & $14 \pm 1.0$ & $14 \pm 1.3$ & $13 \pm 1.0$ \\
\hline \multirow{4}{*}{$\begin{array}{l}\text { Hct } \\
{[\%]}\end{array}$} & w- Sh & $51 \pm 2.8$ & $54 \pm 3.0$ & $59 \pm 1.4$ & $56 \pm 3.0$ & $60 \pm 1.3^{*}$ & $47 \pm 0.8$ & $48 \pm 2.6$ & $50 \pm 1.2$ & $48 \pm 1.3$ \\
\hline & c- Sh & $48 \pm 2.9$ & $51 \pm 4.2$ & $52 \pm 5$ & $51 \pm 4.0$ & $54 \pm 3.5$ & $47 \pm 1.4$ & $42 \pm 1.8$ & $42 \pm 2.2$ & $41 \pm 2.8$ \\
\hline & W- I/R & $53 \pm 3.2$ & $51 \pm 3.1$ & $54 \pm 3.2$ & $50 \pm 3.9$ & $55 \pm 3.5$ & $54 \pm 3.8$ & $49 \pm 4.5$ & $42 \pm 2.9$ & $44 \pm 3.7$ \\
\hline & c- $I / R$ & $50 \pm 2.8$ & $55 \pm 1.9$ & $55 \pm 3.4$ & $55 \pm 2.2$ & $57 \pm 3.1$ & $46 \pm 2.4$ & $47 \pm 2.2$ & $44 \pm 2.4$ & $41 \pm 2.0^{*}$ \\
\hline
\end{tabular}

means \pm S.E. $* p<0.05$ vs base.

$\mathrm{w}-\mathrm{Sh}=$ warm sham-operated group

c- $\mathrm{Sh}=$ cold sham-operated group

$\mathrm{W}-\mathrm{I} / \mathrm{R}=$ warm ischemia-reperfusion group

$c-I / R=$ cold ischemia-reperfusion group

\section{Postoperative days}

\section{Reperfusion}

1 st

2nd

$3 \mathrm{rd}$

h $\quad 30 \mathrm{~min} \quad 60 \mathrm{~min}$

4th

5 th 

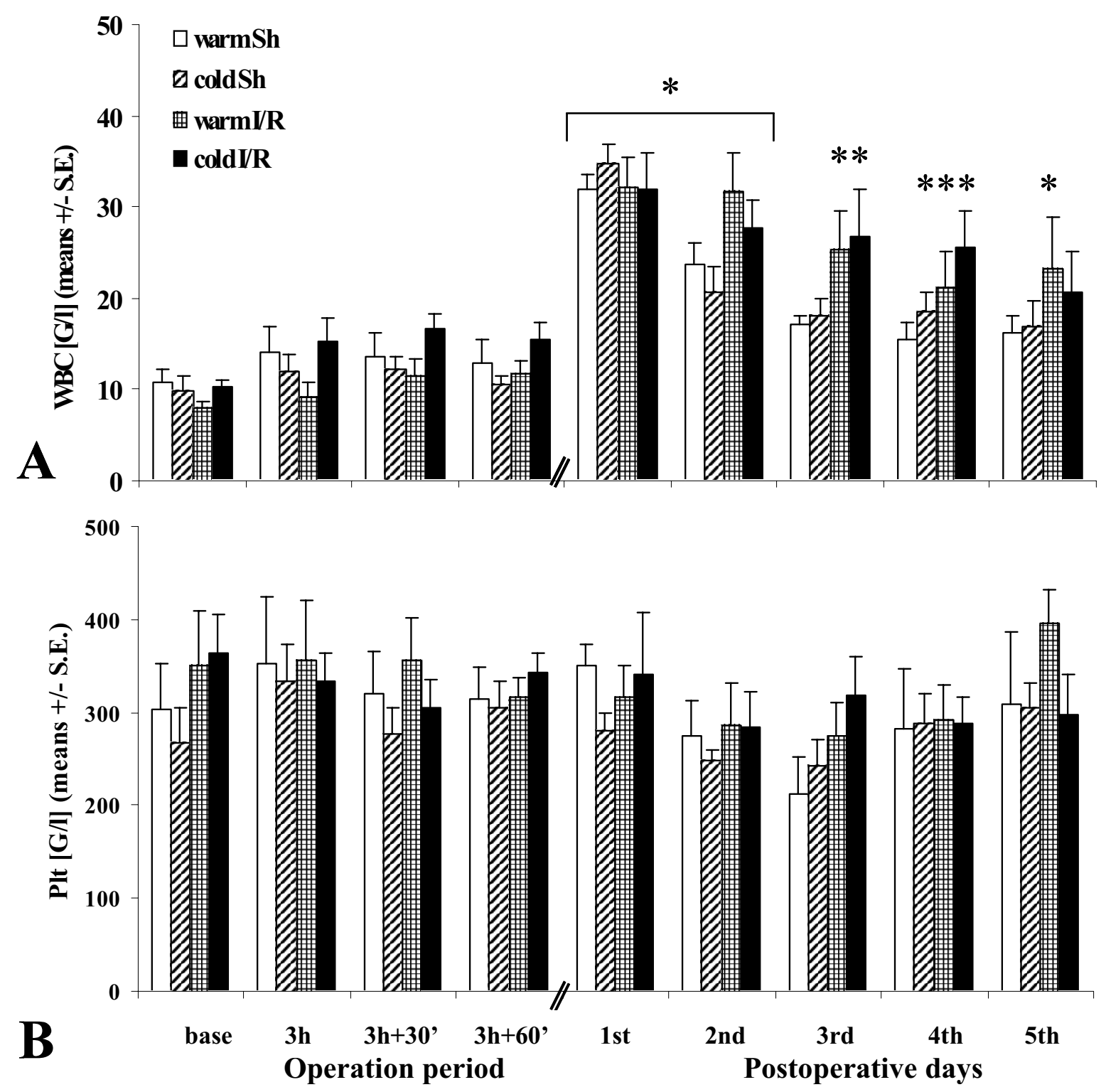

FIGURE 1 - Intraoperative and postoperative changes in (A) white blood cell count (WBC [G/1]) and (B) platelet count (Plt, [G/l]) in the experimental groups.

warm $\mathrm{Sh}=$ warm sham-operated group,

cold $\mathrm{Sh}=$ cold sham-operated group,

warm $\mathrm{I} / \mathrm{R}=$ warm ischemia-reperfusion group

cold $\mathrm{I} / \mathrm{R}=$ cold ischemia-reperfusion group.

$* \mathrm{p}<0.05$ vs. base

Platelet count (Plt) showed slight by the 2nd postoperative day in each group. On the 5 th day Plt expressed in a relatively higher count in the warm I/R group (Figure 1B). The mean platelet volume (MPV) did not change markedly

\section{Coagulation factors}

Prothrombin time (PT) was relatively high in cold I/R group during the first hour of the reperfusion (10-12 sec in average), and on postoperative days, with the highest values on the $3 \mathrm{rd}$ and 4 th days $(16.12 \pm 4.98 \mathrm{sec}, 18.02 \pm 6.25 \mathrm{sec}$, respectively). Unexpectedly, warm Sham group expressed an increase on 2nd - 3rd postoperative day (Figure 2). 


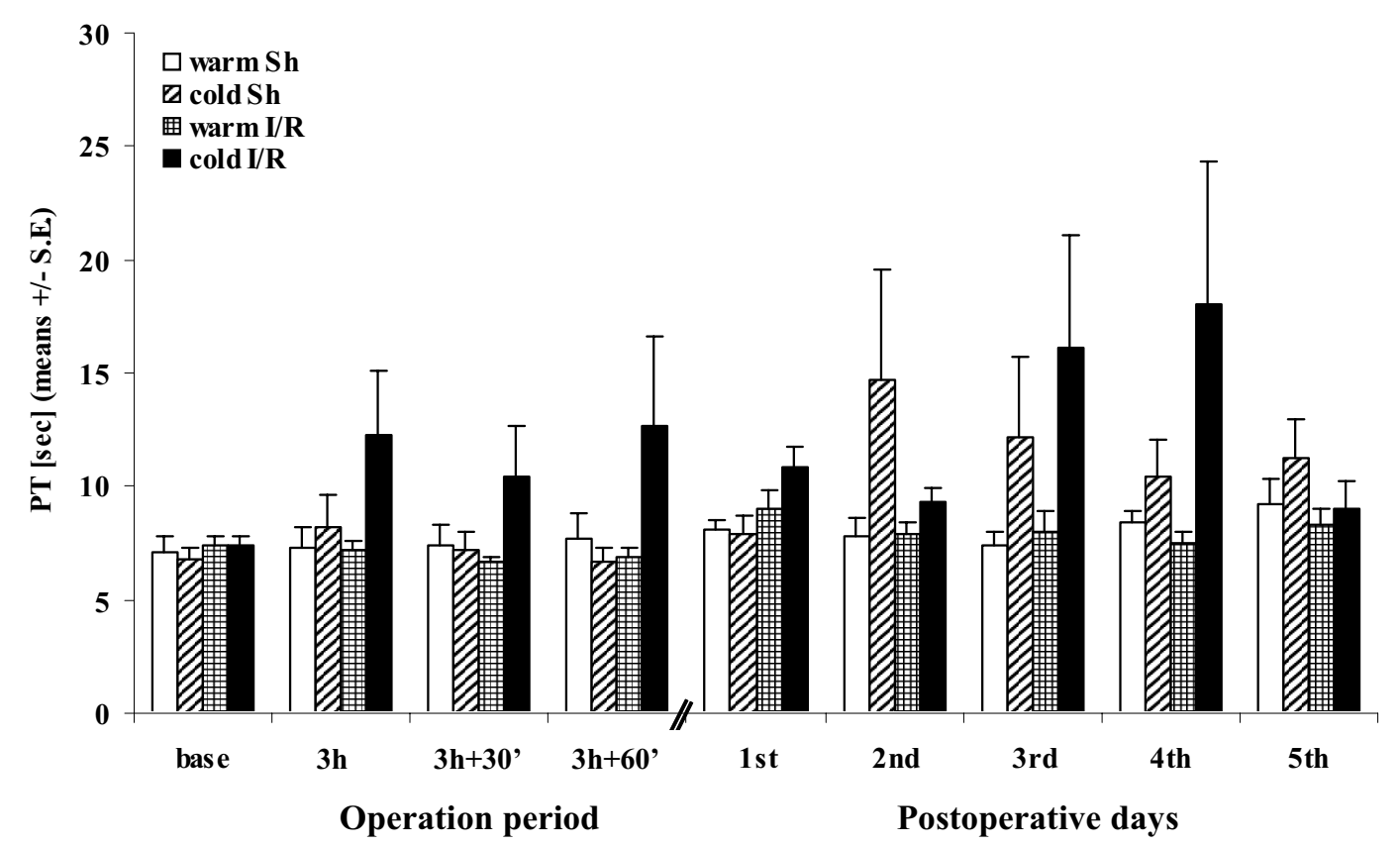

FIGURE 2 - Changes in prothrombin time (PT [sec]) in the experimental groups.

warm $\mathrm{Sh}=$ warm sham-operated group

cold $\mathrm{Sh}=$ cold sham-operated group

warm $\mathrm{I} / \mathrm{R}=$ warm ischemia-reperfusion group

cold $\mathrm{I} / \mathrm{R}=$ cold ischemia-reperfusion group

Activated partial thromboplastin time (APTT) showed remarkable alterations in the postoperative period. It has slightly increased by the 1 st day in each group, and showed further elevation in I/R groups. The maximal increase of APTT was in cold $\mathrm{I} / \mathrm{R}$ group on the 2 nd day $(53.15 \pm 13.18 \mathrm{sec})$, which change was significant compared to its base values and versus the warm sham and warm I/R group too on the 2nd day, and then APTT decreased. In warm I/R group the elevation in APTT was wider in time, its peak was occurred on the 4th day $(42.17 \pm 7.82 \mathrm{sec})]$, but it did not reach the highest values of cold I/R group (Figure 3).

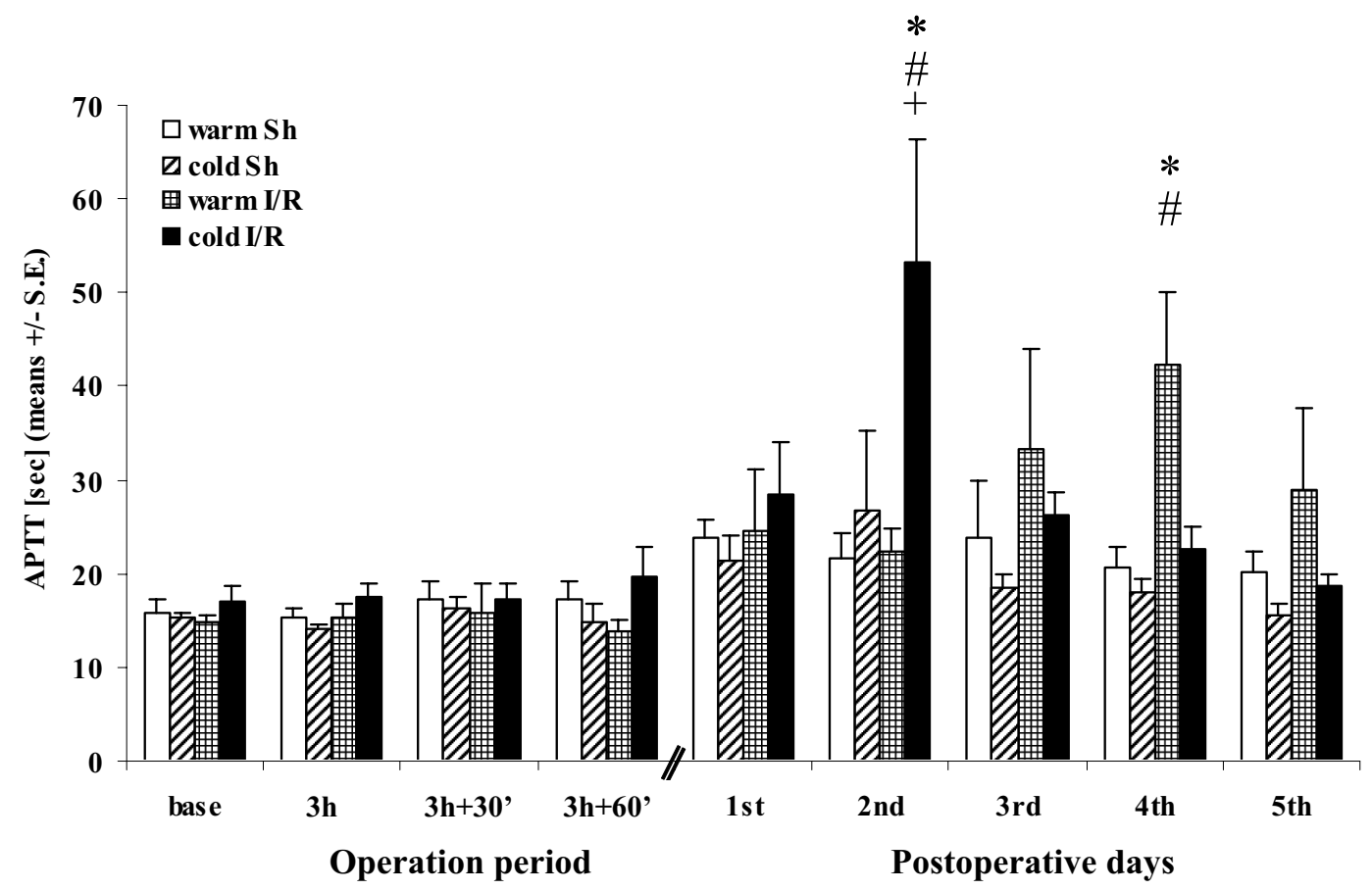

FIGURE 3 - Changes of activated partial thromboplastin time (APTT [sec]) in the experimental groups. $* \mathrm{p}<0.05$ vs. base, $\# \mathrm{p}<0.05$ vs. warm Sh, $+\mathrm{p}<0.05$ vs. warm I/R warm $\mathrm{Sh}=$ warm sham-operated group cold $\mathrm{Sh}=$ cold sham-operated group warm $\mathrm{I} / \mathrm{R}=$ warm ischemia-reperfusion group cold $\mathrm{I} / \mathrm{R}=$ cold ischemia-reperfusion group 
Thrombin time (TT) did not change markedly during the operative period. It showed a slight decrease between the 2 nd and the 5 th days. Warm I/R group expressed a TT elevation on the $1 \mathrm{st}$ and 2 nd day ( $38.46 \pm 6.32 \mathrm{sec}, 31.78 \pm 8.23 \mathrm{sec}$, respectively), while in cold $\mathrm{I} / \mathrm{R}$ group there only was a small elevation on the 2 nd day (Figure 4).

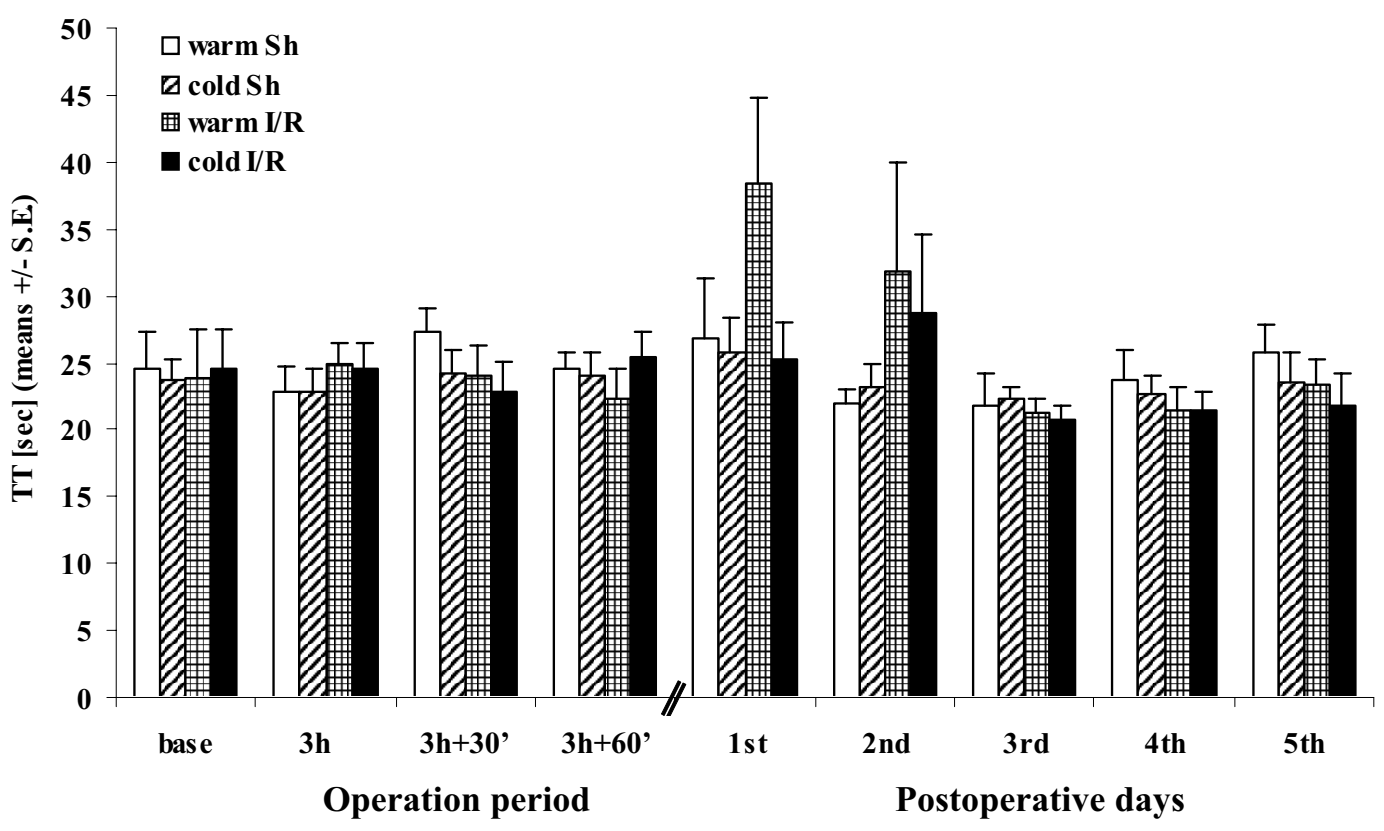

FIGURE 4 - Alterations in thrombin time (TT [sec]) during the experiment and on postoperative days. warm $\mathrm{Sh}=$ warm sham-operated group cold $\mathrm{Sh}=$ cold sham-operated group warm $\mathrm{I} / \mathrm{R}=$ warm ischemia-reperfusion group cold $\mathrm{I} / \mathrm{R}=$ cold ischemia-reperfusion group

In fibrinogen concentration significant changes were not observed during the operative period. From the 1st postoperative day a definite increase was seen in each group, which elevation stabilized between the 3rd and 5th days. The most expressed elevation was expressed by the warm I/R group, where fibrinogen level rose almost for the twofold between the 1st and 2nd day $(\mathrm{p}<0.0001)$ (Table 2).

\section{Total protein and albumin}

Both total protein and albumin concentration changed near similarly in each groups. These decreased by the 1 st postoperative day, and afterwards were partly restored with a tendentious exception for the lower albumin levels in both $\mathrm{I} / \mathrm{R}$ groups on the 1 st to 4 th postoperative days. However, the alterations were not significant (Table 2).

TABLE 2 - Alterations of plasma total protein, albumin and fibrinogen level

\begin{tabular}{|c|c|c|c|c|c|c|c|c|c|c|}
\hline & & \multicolumn{4}{|c|}{ Intraoperative samples } & \multicolumn{5}{|c|}{ Postoperative days } \\
\hline & & Isch & mia & & & & Reperfu & sion & & \\
\hline Parameter & Group & Base & $3 \mathrm{~h}$ & $\begin{array}{c}3+30 \\
\min \end{array}$ & $\begin{array}{c}3+60 \\
\min \end{array}$ & $1 \mathrm{st}$ & 2 nd & $3 \mathrm{rd}$ & 4th & 5 th \\
\hline \multirow{4}{*}{$\begin{array}{c}\text { Total } \\
\text { protein } \\
{[\mathrm{g} / \mathrm{l}]}\end{array}$} & W- Sh & $3 \pm 12.4$ & $65 \pm 7.3$ & $74 \pm 8.6$ & $77 \pm 5.9$ & $59 \pm 6.2$ & $52 \pm 8.1$ & $47 \pm 18.4$ & $40 \pm 9.0$ & $50 \pm 8.6$ \\
\hline & $\mathrm{c}-\mathrm{Sh}$ & $69 \pm 8.9$ & $59 \pm 6.7$ & $57 \pm 10.9$ & $46 \pm 3.5$ & $56 \pm 6.1$ & $65 \pm 16.6$ & $58 \pm 2.7$ & $52 \pm 6.3$ & $69 \pm 12.5$ \\
\hline & W- I/R & $64 \pm 5.8$ & $65 \pm 5.2$ & $60 \pm 3.1$ & $73 \pm 9.6$ & $43 \pm 6.8$ & $50 \pm 9.3$ & $63 \pm 5.9$ & $65 \pm 11.3$ & $52 \pm 6.9$ \\
\hline & $\mathrm{c}-\mathrm{I} / \mathrm{R}$ & $74 \pm 1.0$ & $72 \pm 5.8$ & $70 \pm 6.1$ & $71 \pm 8.2$ & $43 \pm 14$ & $59 \pm 6.8$ & $54 \pm 4.6$ & $50 \pm 9.1$ & $50 \pm 6.7$ \\
\hline \multirow{4}{*}{$\begin{array}{l}\text { Albumin } \\
{[\mathrm{g} / \mathrm{l}]}\end{array}$} & w- Sh & $24 \pm 4.0$ & $26 \pm 5.1$ & $20 \pm 6.3$ & $26 \pm 8.8$ & $19 \pm 3.6$ & $18 \pm 3.6$ & $17 \pm 2.4$ & $23 \pm 3.1$ & $26 \pm 5.0$ \\
\hline & $\mathrm{c}-\mathrm{Sh}$ & $25 \pm 3.5$ & $29 \pm 4.1$ & $29 \pm 4.9$ & $28 \pm 9.9$ & $25 \pm 6.9$ & $15 \pm 3.5$ & $22 \pm 0.9$ & $20 \pm 7.4$ & $29 \pm 13.3$ \\
\hline & W- I/R & $26 \pm 4.5$ & $27 \pm 5.2$ & $20 \pm 3.6$ & $28 \pm 2.7$ & $19 \pm 4.5$ & $16 \pm 1.6$ & $23 \pm 6.6$ & $28 \pm 4.9$ & $20 \pm 7.2$ \\
\hline & c- $I / R$ & $25 \pm 3.6$ & $27 \pm 5.6$ & $24 \pm 4.2$ & $30 \pm 8.6$ & $13 \pm 6.8$ & $14 \pm 3.1$ & $22 \pm 3.6$ & $22 \pm 9.2$ & $24 \pm 8.8$ \\
\hline \multirow{4}{*}{$\begin{array}{c}\text { Fibrinogen } \\
{[\mathrm{g} / \mathrm{l}]}\end{array}$} & w-Sh & $3.4 \pm 0.3$ & $3.4 \pm 0.4$ & $3.6 \pm 0.2$ & $3.6 \pm 0.4$ & $4.0 \pm 0.6$ & $4.0 \pm 0.7$ & $4.6 \pm 0.3^{*}$ & $4.6 \pm 0.5^{*}$ & $4.5 \pm 0.3^{*}$ \\
\hline & c- Sh & $3.1 \pm 0.6$ & $3.2 \pm 0.5$ & $3.2 \pm 0.5$ & $3.1 \pm 0.7$ & $3.8 \pm 0.7^{*}$ & $4.5 \pm 0.4^{*}$ & $4.5 \pm 0.4^{*}$ & $4.5 \pm 0.4^{*}$ & $4.4 \pm 0.5$ \\
\hline & W- I/R & $2.3 \pm 0.2$ & $2.5 \pm 0.3$ & $2.6 \pm 0.3$ & $2.4 \pm 0.3$ & $2.8 \pm 0.3$ & $5.0 \pm 0.1 *$ & $5.1 \pm 0.3^{*}$ & $5.3 \pm 0.2^{*}$ & $5.0 \pm 0.2^{*}$ \\
\hline & c- I/R & $3.5 \pm 0.5$ & $3.9 \pm 0.5$ & $3.9 \pm 0.5$ & $3.9 \pm 0.5$ & $4.8 \pm 0.3$ & $5.1 \pm 0.3^{*}$ & $5.6 \pm 0.4^{*} \#$ & $5.2 \pm 0.4^{*}$ & $5.4 \pm 0.1$ *\# \\
\hline
\end{tabular}

means \pm S.E. $\quad * p<0.05$ vs base. $\quad \# p<0.05$ vs. warm Sh.

$\mathrm{w}-\mathrm{Sh}=$ warm sham-operated group, $\mathrm{c}-\mathrm{Sh}=$ cold sham-operated group, $\mathrm{w}-\mathrm{I} / \mathrm{R}=$ warm ischemia-reperfusion group, $\mathrm{c}-\mathrm{I} / \mathrm{R}=\mathrm{cold}$ ischemia-reperfusion group. 
Parameters of the samples from the excluded limb region

Parameters of the blood samples taken locally from the femoral vein of the excluded limb -just before the clamp release after 3 hours of ischemia- are shown in Table 3.

Leukocyte counts were elevated both in warm and cold excluded blood versus base values. In cold I/R group this deviation was significant $(10.32 \pm 0.82 \mathrm{G} / 1$ vs. $15.25 \pm 1.54$ $\mathrm{G} / \mathrm{l}, \mathrm{p}=0.0378$ ). In systemic samples taken just after 3-hour ischemia showed slightly elevated leukocyte counts compared to the excluded blood. Monocyte-granulocyte ratio and counts were moderately lower comparing to the base or the systemic values just after ischemia.

Red blood cell counts were significantly higher in excluded blood versus base (warm I/R base: $7.21 \pm 0.39 \mathrm{~T} / 1, \mathrm{p}=0.0139$, cold I/R base: $6.98 \pm 0.35 \mathrm{~T} / 1, \mathrm{p}=0.0229$ ) and the systemic values just after the ischemic period (in warm I/R p=0.0164).

Hematocrit showed the same tendency with a significant difference between base and excluded blood, even between excluded and systemic blood taken just after ischemia (in warm I/R group base: $52.84 \pm 3.14 \%$, p=0.001, systemic $3 \mathrm{~h}: 51.44 \pm 3.08 \%$, $\mathrm{p}<0.001$; in cold I/R group base: $51.32 \pm 2.69 \%, \mathrm{p}=0.0023$, systemic $3 \mathrm{~h}$ : $54.82 \pm 1.92 \%, \mathrm{p}=0.0104$, respectively). Values of warm I/R group were higher than in cold group, showing a significant difference in Hct.

Platelet count was extremely low in the excluded blood of warm I/R group. The difference was significant compared to base values $(350.6 \pm 58.47 \mathrm{G} / 1, \mathrm{p}=0.0079)$, to the systemic values at the beginning of the reperfusion $(355.4 \pm 65.92 \mathrm{G} / \mathrm{l}, \mathrm{p}=0.004)$, and versus cold $\mathrm{I} / \mathrm{R}$ excluded blood $(\mathrm{p}<0.001)$. In cold $\mathrm{I} / \mathrm{R}$ group there was a mild decrease in excluded blood, being significant compared to base $(364.42 \pm 41.64 \mathrm{G} / 1, \mathrm{p}=0.018)$ and to systemic values (333.16 $\pm 29.71 \mathrm{G} / 1, \mathrm{p}=0.0335)$.

In warm I/R group coagulation factors were higher than the base or systemic values as followings: prothrombin time (base: $7.44 \pm 0.41 \mathrm{sec}$, excluded: $12.15 \pm 4.56 \mathrm{sec}$, systemic $3 \mathrm{~h}$ : $7.2 \pm 0.39 \mathrm{sec}$ ), activated partial thromboplastin time (base: $14.83 \pm 0.67 \mathrm{sec}$, excluded: $20.03 \pm 2.37 \mathrm{sec}$, systemic $3 \mathrm{~h}$ : $15.26 \pm 1.41 \mathrm{sec}$ ) and moderately in the case of thrombin time (base: $23.84 \pm 3.76 \mathrm{sec}$, excluded: $24.4 \pm 1.2 \mathrm{sec}$, systemic $3 \mathrm{~h}$ : $24.84 \pm 1.58 \mathrm{sec})$.

In cold $\mathrm{I} / \mathrm{R}$ group the changes were different. Comparing to the base values $(7.37 \pm 0.42 \mathrm{sec})$ prothrombin time was slightly higher in excluded blood $(8.85 \pm 1.75 \mathrm{sec})$, and was elevated in systemic samples taken at the beginning of the reperfusion $(12.21 \pm 2.93 \mathrm{sec})$. Activated partial thromboplastin time was remarkably elevated in excluded blood (base: $16.98 \pm 1.74 \mathrm{sec}$, excluded: $24.62 \pm 3.8 \mathrm{sec}$, systemic $3 \mathrm{~h}: 17.55 \pm 1.31 \mathrm{sec}$ ), while thrombin time was lower in excluded blood than in base $(24.55 \pm 2.96 \mathrm{sec})$ or systemic samples $(24.57 \pm 1.87 \mathrm{sec})$.

Total protein and albumin levels were lower, while fibrinogen concentration was higher in excluded blood compared to base or systemic samples in $\mathrm{I} / \mathrm{R}$ groups.

\section{Discussion}

\section{Effect of ischemia-reperfusion}

Ischemia of the extremities may harmful not only for the tissues of the affected region but it may jeopardize farther tissues and organs too. During reperfusion the excluded blood returns to the systemic circulation, causing serious alterations eliciting metabolic changes, rhabdomyolysis and the cascade effect of inflammatory processes depending on duration, temperature and degree of the ischemia ${ }^{3-9}$.

Skeletal muscle is the predominant tissue in the limb but also the tissue that is most vulnerable to ischemia being determinative for the outcome. Physiological and anatomical studies show that irreversible muscle cell damage starts after 3 hours of ischemia and is nearly complete at 6 hours. These muscle changes are paralleled by progressive microvascular damage $e^{6,20}$. On human skeletal muscle normothermia of $34-35^{\circ} \mathrm{C}$ yielded a critical ischemia of 2 and a quarter hours, and an ischemic tolerance of 5 hours presupposes a muscle temperature of less than $26^{\circ} \mathrm{C}^{21}$. In most instances of reperfusion, which follows thrombotic or embolic occlusion, there is a variable degree of ischemic damage in the zone where collateral blood flow is possible. The extent of this region determines the magnitude of the local or systemic inflammatory responses.

Following limb ischemia-reperfusion the early postoperative period, mainly the first 3 days, may have a crucial importance in respect of coagulopathy. We found that activated partial thromboplastin time was elongated on early postoperative period, prothrombin time values showed moderate elevation, while fibrinogen continuously increased.

Little number of studies deals with the hemostaseological and blood coagulation changes after ischemia-reperfusion on limbs with healthy vasculature. The background of the appearing hyper- or hypocoagulable states has not been completely clarified yet. 
Nielsen and Geary described ${ }^{22}$ that after hepatoenteric ischemia-reperfusion coagulopathy clot formation may appear in rabbits. Supposedly this coagulopathy could be caused by the release of mast-cell-derived heparin, and xanhine-oxidase (XO) inhibition stabilizes mast cells. Thus, XO inactivation may result in clot formation ${ }^{22}$. It is known that during ischemia-reperfusion $\mathrm{XO}$ activity increases, that may contribute to the release of mast-cell-derived heparin, and so, affecting the coagulation time parameters. Haithcock and co-workers ${ }^{23}$ investigated the cause of the coagulopathy seen with supraceliac aortic cross-clamping in a porcine model. They measured prothrombin time, activated partial thromboplastin time, fibrinogen concentration, platelet count and thrombin-antithrombin complexes, while fibrinolytic pathway activation was assessed with levels of tissue plasminogen activator (PA) antigen and tissue PA activity, PA inhibitor-1 and 2-antiplastin activity. They found that 30 and 60 minutes of aortic clamping resulted in similar degrees of intravascular thrombosis and fibrinogen depletion. They could demonstrate that the major hemostatic alteration is activation of fibrinolytic pathways, of which magnitude is directly related to the duration of aortic clamping ${ }^{23}$.

Besides changes in blood coagulation factors, on postoperative days we found non-specific alterations in hematological parameters. Hemoconcentration, elevation of fibrinogen level accompanied by the changes in leukocyte and platelet count, increased whole blood and plasma viscosity, altogether might be a consequence of the surgical interventions ${ }^{24}$. These changes were larger in scale and significant after ischemia-reperfusion.

We found, that beside the rise in fibrinogen level, albumin decreased on $1 \mathrm{st}-4$ th postoperative days after ischemia-reperfusion; however the changes were not large in scale. Decrease in albumin level can be caused partly by the general effects of operation and nutritional state. Furthermore, it is known that the ischemic-insulted cell membrane becomes permeable for albumin, therefore intracellular albumin is an early marker of cell damage ${ }^{25,26}$. Hvaal and co-workers described that in limb ischemia-reperfusion injury mainly the ischemic phase is correspondent for intracellular albumin accumulation ${ }^{27}$.

In the presented experiment the examination of the blood that was excluded for 3 hours in the cold or warm ischemic leg, has yielded interesting findings. However, in the light of the fact that composition of blood can be altered during stasis, it is also supposed that the parameters describing quantitative or qualitative properties of blood cells might be distorted. During 3 hours of ischemia/stasis the possible endothelial damage may affect the leukocyte-platelet accumulation, contributing endothelial dysfunction. During stasis changes in vessel permeability, consequent fluid distribution is partly the background of the hemoconcentration and the found changes in plasma proteins.

\section{Effects of cooling}

It is suggested that cooling does not mean always a benefit, mainly in respect of the excluded blood. Earlier we described that during warm ischemia the local metabolic and physical changes caused impairing of red blood cell deformability, while hematocrit and whole blood viscosity was higher during cold ischemia (the measurements were performed at constant temperature) ${ }^{19}$. Furthermore, we found that activated partial thromboplastin time and leukocyte count was more elevated in cold ischemia, but platelet count decreased extremely in warm ischemia. The background of these alterations can be related to the local metabolic and physical changes and the differences in accumulation of leukocytes and platelets being adhered to the endothelial wall.

In our study investigation of the effects of cooling had a crucial importance, though, real effectiveness of cooling is still controversial. Hypothermia is known to increase the ischemic tolerance of the skeletal muscle ${ }^{12,13}$, in contrast, cooling affects the hemorheological factors ${ }^{19,28}$. Our workgroup observed impaired red blood cell deformability after 3-hour hind limb ischemiareperfusion, which was more expressed after cooling ${ }^{19}$.

Despite benefits of hypothermia in elective surgery, in certain trauma cases hypothermia is one of the most frequent causes of posttraumatic complications. Hypothermia induced by active cooling in elective surgery preserves well the ATP pool maintaining the aerobic metabolism, while in trauma patients hypothermia caused by decreased heat generation leads to ATP depletion under anaerobic metabolic condition ${ }^{15}$. Cellular depletion of ATP is in connection with the irreversibility of ischemic processes $^{29}$. The 3-hour ischemia that we used in our experiment might influence the mitochondrial function, resulting in a decreased ATP and phosphocreatine level ${ }^{30}$. Otherwise, postischemic hypothermia may increase the interstitial muscle $\mathrm{pH}$ and reduce postreperfusion muscle edema ${ }^{31}$.

The optimum of cooling has not been identified. Osterman and his workgroup ${ }^{14}$ proved the efficacy of cooling in ATP preservation using ${ }^{31}$ phosphorus-NMR spectroscopy during amputated hind limb ischemia in a feline model, and they concluded that the empirical benefit derived by cooling muscle in an iced medium may actually be related to the cellular alkalization produced by tissue cooling, as this significantly mitigates the profound acidosis that would otherwise occur ${ }^{14}$. Furthermore, it has been demonstrated that hypothermia and acidosis cause a clinical coagulopathy with different kinetics ${ }^{32}$.

\section{Conclusions}

This study describes coagulopathy and other hematological effects comparing normo- and hypothermic limb ischemia-reperfusion.

The main conclusions are: (1) Three-hour ischemia and the following reperfusion resulted in both non-specific and specific changes in hematological and hemostasis parameters, which alterations were enlarged in the case of cold ischemia. (2) The composition of blood that was excluded in the limb during ischemia showed several pathological changes, and the benefits of cooling were controversial. (3) It is supposed that uncontrolled and non-optimal cooling during ischemia need more vigilance, because it can enlarge the harmful effect of the ischemia and the reperfusion, and in the light of the complex pathophysiological events and the actual clinical state it may cause serious problems jeopardizing the outcome. (4) Data indicate a risk of coagulopathy following limb ischemia-reperfusion on early post-eventually days, which risk is higher in the case of cold ischemia-reperfusion.

\section{References}

1. Haimovici H. Arterial embolism with massive ischaemic myopathy and myoglobinuria. Surgery. 1960;47:739-47. 
2. McCutcheon C, Hennessy B. Systemic reperfusion injury during arm replantation requiring intraoperative amputation. Anaesth Intensive Care. 2002;30:71-3.

3. Defraigne JO, Pincemail J. Local and systemic consequences of severe ischemia and reperfusion of the skeletal muscle. Physiopathology and prevention. Acta Chir Belg. 1998;98:176-86.

4. Ouriel K, Veith FJ. Acute lower limb ischemia: determinants of outcome. Surgery. 1998;124:336-42.

5. Anaya-Prado R, Toledo-Pereyra LH, Lentsch AB, Ward PA. Ischemia/reperfusion injury. J Surg Res. 2002;105:248-58.

6. Blaisdell FW. The pathophysiology of skeletal muscle ischemia and the reperfusion syndrome: a review. Cardiovasc Surg. 2002;10:620-30.

7. Yassin MM, Harkin DW, Barros D'Sa AA, Halliday MI, Rowlands BJ. Lower limb ischemia-reperfusion injury triggers a systemic inflammatory response and multiple organ dysfunction. World J Surg. 2002;26:115-21. 8. Kabaroudis A, Gerassimidis T, Karamanos D, Papaziogas B, Antonopoulos V, Sakantamis A. Metabolic alterations of skeletal muscle tissue after prolonged acute ischemia and reperfusion. J Invest Surg. 2003;16:219-28

9. Lai EW, Toledo-Pereyra L, Walsh J, Lopez-Neblina F, Anaya-Prado R. The role of MAP kinases in trauma and ischemia-reperfusion. J Invest Surg. 2004; 17:45-53.

10. Armand R, Hess JR. Treating coagulopathy in trauma patients. Transfus Med Rev. 2003;17:223-31.

11. Schreiber MA. Coagulopathy in the trauma patient. Curr Opin Crit Care. 2005;11-590-7.

12. Hamel AL, Moe JH. Effect of total ischemia on hind limbs of dogs subjected to hypothermia. Surgery. 1964;55:274-80.

13. Presta M, Ragnotti G. Quantification of damage to striate muscle after normothermic or hypothermic ischemia. Clin Chem. 1981;27:297-302.

14. Osterman AL, Heppenstall RB, Sapega AA, Katz M, Chance B, Sokolow D. Muscle ischemia and hypothermia: a bioenergetic study using 31 phosphorus nuclear magnetic resonance spectroscopy. J Trauma. 1984;24:811-7.

15. Seekamp A, van Griensven M, Hildebrandt F, Wahlers T, Tscherne H. Adenosine-triphosphate in trauma-related and elective hypothermia. J Trauma. 1999;47:673-83.

16. Tsuei BJ, Kearney PA. Hypothermia in the trauma patient. Injury. 2004;35:7-15.

17. Szokoly M, Acs G, Nemeth N, Nagy D, Furka I, Miko I. Correlation between clinical cases and an experimental amputate model. Eur Surg Res. 2003;35:314. [Abstract]

18. Szokoly M, Nemeth N, Brath E, Acs G, Hamar J, Miko I., Furka I. Experimental 'functional amputate' model in ischemia-reperfusion. Magy Seb. $2005 ; 58: 138-43$.
19. Nemeth N, Szokoly M, Acs G, Brath E, Lesznyak T, Furka I, Miko I. Systemic and regional hemorheological consequences of warm and cold hind limb ischemia-reperfusion in a canine model. Clin Hemorheol Microcirc. 2004;30:133-45.

20. Duran WN, Takenaka H, Hobson RW. Microvascular pathophysiology of skeletal muscle ischemia-reperfusion. Semin Vasc Surg. 1998;11:203-14.

21. Eckert P, Schnackerz K. Ischemic tolerance of human skeletal muscle. Ann Plast Surg. 1991;26:77-84.

22. Nielsen VG, Geary BT. Coagulopathy mediated by hepatoenteric ischemia-reperfusion in rabbits: role of xanthine oxidase. Transplantation. 2002;74:1181-83.

23. Haithcock BE, Shepard AD, Raman SBK, Conrad MF, Pandurangi K, Fanous NH. Activation of fibrinolytic pathways is associated with duration of supraceliac aortic cross-clamping. J Vasc Surg. 2004;40:325-33. 24. Koppensteiner R. Blood rheology in emergency medicine. Semin Thromb Hemost. 1996;22:89-91.

25. Kupinski AM, Shah DM, Bell DR. Transvascular albumin flux in rabbit hindlimb after tourniquet ischemia. Am J Physiol. 1993;264(3 Pt 2):H901-8. 26. Kupinski AM, Bock DE, Bell DR. Skeletal muscle ischemia-reperfusion causes transitory increase in microvascular protein permeability. Am J Physiol. 1997;273:H303-9.

27. Hvaal K, Svindland A, Nordsletten L, Skjeldal S. No increasing injury during early reperfusion of skeletal muscle. Scand J Clin Lab Invest. 1996;56:11-6.

28. Barbee JH. The effect of temperature on the relative viscosity of human blood. Biorheology. 1973;10:1-5.

29. Brandao ML, Roselino JES, Piccinato CE, Cherri J. Mitochondrial alterations in skeletal muscle submitted to total ischemia. J Surg Res. 2003;110:235-40.

30. Hartung KJ, Jung K, Minda R, Kuncz W. Mitochondrial respiratory function as indicator of the ischemic injury of the rat kidney. Biophys Biochim Acta. 1985;44:1435-43.

31. Wright JG, Araki CT, Belkin M, Hobson RW. Postischemic hypothermia diminishes skeletal muscle reperfusion edema. J Surg Res. 1989;47:389-96. 32. Martini WZ, Pusateri AE, Uscilowicz JM, Delgado AV, Holcomb JB. Independent contributions of hypothermia and acidosis to coagulopathy in swine. J Trauma. 2005;58:1002-9.

\section{Acknowledgments}

Authors are grateful to the technical staff of the Department of Operative Techniques and Surgical Research. Grants: The Hungarian Scientific Research Fund (Grant Nr.: OTKA T-032571, OTKA K-67779) and The Hungarian Ministry of Health Medical Research Council (Grant Nr.: 6003/1/2001/ETT).

\section{Correspondence:}

Conflict of interest: none Norbert Nemeth

Financial source: none

Department of Operative Techniques and Surgical Research

Medical and Health Science Center, University of Debrecen

H-4032 Debrecen, Nagyerdei krt. 98., Hungary

Phone/Fax: +36-52-416-915

nemeth@med.unideb.hu

Received: March 18, 2009

Review: May 12, 2009

Accepted: June 16, 2009

\section{How to cite this article}

Szokoly M, Nemeth N, Furka I, Miko I. Hematological and hemostaseological alterations after warm and cold limb ischemia-reperfusion in a canine model. Acta Cir Bras. [serial on the Internet] 2009 Sept-Oct;24(5). Available from URL: http://www.scielo.br/acb 